\title{
Ownership Structure, Capital Structure, and Firm Survival
}

\author{
Mehdi Rasouli Ghahroudi ${ }^{1}$, Yasuo Hoshino ${ }^{2} \&$ Ehsan Fakhraei ${ }^{1}$ \\ ${ }^{1}$ Institute for Management and Planning Studies (IMPS), Tehran, Iran \\ ${ }^{2}$ University of Tsukuba, Tsukuba, Japan \\ Correspondence: Mehdi Rasouli Ghahroudi, Institute for Management and Planning Studies (IMPS), Tehran, Iran. \\ Tel: 98-910-212-9919. E-mail: m.rasouli@imps.ac.ir
}

Received: September 14, 2019

Accepted: October 4, 2019

Online Published: October 8, 2019

doi:10.5539/ijef.v11n11p19

URL: https://doi.org/10.5539/ijef.v11n11p19

\begin{abstract}
This study investigates the influence of ownership structure and capital structure on the survival of firms on Iran's stock market from 2005 to 2015. Firm survival is measured in terms of the exit of the firm " $\mathrm{i}$ " in year " $\mathrm{t}$ " from among 484 firms listed in the Tehran Stock Exchange. We have used a binary logistic regression method to test the hypotheses. The results reveal a significant inverse relationship between capital structure and firm survival and between major ownership and firm survival on the stock market, as well as a significant direct relationship between institutional ownership and firm survival. Thus, firms with a higher ratio of debt to assets have a higher probability of survival. However, those with a higher ratio of institutional ownership are less likely to survive.
\end{abstract}

Keywords: capital structure, institutional ownership, major ownership, survival, stock market

\section{Introduction}

A firm's lower dependence on debt and its financial stability, in the long run, are likely more important factors with respect to firm survival than is a strictly profit-making strategy (Baumöhla et al., 2019; Guariglia et al., 2016; Görg \& Spaliara, 2014). Thus, institutional investors are the main actors in financial markets. They are important and influential in corporate governance due to the privatization policies adopted by emerging countries. Moreover, Institutional owners play a key role in firms' monitoring of the equity they hold. Firm owners (shareholders) have various rights. One of them is the right to select the board of directors, which serves to monitor firm managers' performance. Major shareholders play a significant role in the transfer of information to other shareholders. They can obtain private information from management and transfer it to others (Najjar \& Taylor, 2008).

Whether a firm is listed on a stock exchange is shown to be an indicator of lowering survival probability. The fact that being listed is a risk factor might be due to some specific conditions in the country (Baumöhla et al., 2019). During the transformation process from centrally planned to a market-oriented economy, Tehran stock exchange (TSE) ended up with excessively large numbers of listed firms as a result of mass privatization.

The importance of the capital structure issue is also made clear in Modigliani and Miller (1958), who argue that there is no difference between equity financing and debt financing in terms of firm value, that no firm financing method provides additional value, and thus that managers face no restrictions regarding method selection. However, further empirical evidence refuted that view. Modigliani and Miller (1963) also offered new findings that make the importance of firms' capital structure clearer than ever. Several studies on firm financing try to explain the impact of capital structure on firm value (Asadi et al., 2011). The tendency for state ownership in some industrial sectors (for example, oil and power) is more prevalent. It is also acceptable for countries to extend the existence of strategic companies with their own guarantees and for political reasons. Further, in countries with weak institutions or poor investor protection, state ownership can increase the value of partially privatized companies by providing monitoring and control of minority shareholders from been exploitation by private owners (Megginson, 2016; Baumöhla et al., 2019 ).

Significant studies have been conducted in the field of performance, and much attention has been paid to the factors affecting firms' birth, death, and lifespan in the US and Europe. However, few studies have been conducted on the survival of firms in Iran. This study investigates the capital structure and firm ownership and their implications on the survival of firms listed on the Tehran Stock Exchange. 
In this study, we aim to bridge the gap in empirical research in two ways; first, we contribute to the literature by analyzing how ownership structure affects firm survival probability while controlling for a number of financial and other firm-specific factors. Second, we analyze firm survival in a stock market of an emerging market where the majority ownership and the varying level of capital structures represent an important issue.

\section{Literature Review}

The aim of companies in the stock market and their managers is to maximize equity value - in other words, to maximize the value of a firm and its stocks (Namazi \& Kermani, 2008). Maximizing firm value requires the optimal use of financial resources, as well as adequate returns and risk. Ensuring effective shareholder governance of firm management and maximizing firm value are the most basic elements of corporate governance. Given the role played by capital structure and ownership structure in a firm's management and financial position, an awareness of both is necessary for the development of the strategies required to ensure firm survival and continuity. The survival of new firms is important for economic growth and development, but their survival rate is low (Shane, 2000): about 40 percent of firms operate for about one year (Taylor, 1999) and about 60 percent survive for about five years (Kirchhoff, 1994). Most studies show that the probability of firm survival differs significantly depending on firm attributes; however, there is no consensus about the importance of attributes in describing the heterogeneity across survival rates (Audretsch et al., 1997). Previous studies indicated that the corporate level, institutions have an impact on firm performance (Yasar et al., 2011; Rasouli, 2011, 2016; Ghoul et al., 2017; Fidrmuc et al., 2017; Faruq \& Weidner, 2018). Despite these studies, the role of institutions has been largely neglected with respect to firm survival (Che et al., 2017).

Pecking order theory concerns the choice between debt and equity in a firm's capital structure and is based on the information asymmetry between management and the firm's extra-organizational investors. Ross (1977) was the first to discuss the debt tool as a signaling mechanism, arguing that this tool can be used amid the information asymmetry between management and extra-organizational investors. Management has more information about the firm's financial situation and its current and projected future performance than extra-organizational investors do and will try to avoid contracting debt when the firm is underperforming because the probability of default and bankruptcy will increase. Myers and Majluf (1984) introduced a more complex form of this model and argued that what forms a capital structure is the firm's desire to provide the required financial resources. For this purpose, the firm first turns to internal resources; if internal resources are insufficient, the firm will turn to risk-free debt or debt with little risk, risky debt, and stocks, in that order. Among stocks, preferred stocks are preferred to common stocks. This hierarchy of financing is encountered when the cost of issuing new securities exceeds other costs and benefits from dividends and debt.

The "density delay" hypothesis posits that organizations established when their industry is highly dense have a higher exit rate than organizations set up when their industry is less dense. According to the industrial organization theory, most new companies are at suboptimal levels and consequently face costly disadvantages that make their survival more difficult. For firms that are able to survive, reducing these costs is a significant achievement (Lomi \& Larsen, 1998).

The static trade-off theory (Kraus \& Litzenberger, 1973; Myers \& Majluf, 1984) assumes that firms seek an optimal capital structure formed through a combination of financing resources in which the debt financing costs and interests are equal. The theory also assumes that the ratio of the firm's financial leverage to its purpose should be optimal and that markets interpret any deviation (either increase or decrease) from that ratio as bad news. This optimal financial leverage can be attained through a trade-off between the costs and benefits of additional debt.

Our research is in firms' ownership structure and capital structure, which are both often neglected in the survival literature. Several studies have addressed the impact of ownership on firm performance (Rasouli, 2011; Wang \& Shailer, 2015; Rasouli et al., 2010; Baumöhl et al., 2019). In fact, there are two theoretical hypotheses that explain both a positive relationship between major ownership and firm survival (the alignment hypothesis; see Shleifer \& Vishny, 1986; Baumöhl et al., 2019) and a negative relationship between major ownership and firm survival (the expropriation hypothesis; see Claessens et al., 2000; Baumöhl et al., 2019).

Corporate ownership through stock ownership has a significant impact on how firms are controlled. Jensen and Meckling (1976) introduced the foundations of agency theory, wherein the manager is the agent and the shareholder is the employer. In their analysis, the shareholder operates against the manager, and the presence of major shareholders exerts pressure on managers and influences their behavior; major shareholders can also pressure board members to request a manager's dismissal when the firm is performing poorly (Ely \& Song, 2000). Abdullah (2006) and Elloumi and Gueyle (2001) report an inverse relationship between major ownership 
and financial distress has given agency costs. The literature considers institutional shareholders to play a role similar to that of major shareholders due to their considerable power and influence. For example, Elsayed and Wahba (2013) believe that institutional shareholders play an active and effective role in monitoring management's behavior and decisions.

Morikawa (2013) reports that the annual growth rate of family firms' productivity is $2 \%$ lower than that of non-family firms, but their probability of survival is 5 to $10 \%$ higher. Iwasaki (2014) finds that boards of directors and audit committees play vital roles in reducing the potential risks of firm exit and that improving corporate governance can increase the likelihood of firm survival. Mas-Vordu et al. (2015) show, using a combination of these variables, that the size of the business unit can be an important factor in firm survival. Using data from Britain, Germany, France, Sweden, Italy, and Spain, Useche (2015) finds a significant relationship between a firm's patenting status and survival after controlling for key variables, such as age, size, sales, and profitability.

Wilson et al. (2013) use a unique dataset comprising data on more than 700,000 family and non-family private companies in the UK covering 2007 to 2010 to identify board characteristics related to corporate survival/failure. They conclude that such board characteristics are important factors in the likelihood of survival for family firms.

Wahlqvist (2014) explores capital and ownership structures and their relationship with the survival of newly established family firms between 2001 and 2011. The study concludes that newly established family firms are more likely to accept debt, especially long-term debt with a high degree of ownership, than are other family firms and that heavily indebted family firms are less likely to survive than are other non-family firms.

Velu (2015) studied data on 129 new e-commerce companies in the US securities market between 1995 and 2004 using a Cox model, finding that new companies with a high or low innovation model had a higher probability of survival than new companies with a modest business model. The study also shows that partnerships with third-party firms with supplementary assets reduce the survival rate of new firms as business model innovation intensifies.

Liang et al. (2015) examine the relationship between bank survival and cost-efficiency in 47 commercial banks in Taiwan between 2000 and 2008. Using a logistic regression model, the study extracts the four key factors that may affect bank survival. It finds that following: (1) Bank survival or failure is affected by the ratio of debt, inactive loans, asset growth rates, and bank ownership; (2) failed banks have a higher debt ratio and a higher share of inactive loans; (3) government banks are more cost-effective than private banks; and (4) failed banks have lower average returns than surviving banks.

Rasouli and Hoshino (2007) examine the effects of equity ownership, size, entry strategy and subsidiary age on the sales growth ratio and the subsidiary's survival. their results indicated that capital, the age of the venture, the number of employees and full equity ownership affects survival.

Guariglia et al. (2016) study the impact of interest on company survival. Data on a group of UK companies covering 2000 to 2009 were examined using a Cox model. The findings show that interest had a more powerful impact during the recent financial crisis than it had in more relaxed periods and that changes in interest rates had a significant impact on company survival. The study also shows that younger and non-export bank corporations, which are strongly affected by changes in interest rates, especially during a crisis, were more likely to survive. The study also finds a strong and reciprocal relationship between debt service costs and company survival and concludes that companies are most likely to fail because of low cost-effectiveness.

Dellana and West (2016) use a Cox proportional hazards regression to compare three-year financial data across 69 non-bankrupt and 74 bankrupt organizations. The study discusses how the "survival function" offers valuable information about whether bankruptcy may occur; this information allows members of the supply chain to be classified into three groups: fast-moving healthy companies, companies with a potential bankruptcy, and companies with high-risk levels that need to be monitored.

Khalili et al. (2009) show that coaxial model variables, including environmental risk, firm strategy, and capital structure, affect the performance of petrochemical firms. Zeinali and Mohammad Shilan (2011) find a significant relationship between a firm's financial structure and its size in the pharmaceutical industry. Rahimian et al. (2013) find a U-shaped relationship between capital structure and performance/value for firms listed on the Tehran Stock Exchange. Rezaei (2013) reveals a positive and significant relationship between the industry entrance rate and firm survival, as well as a positive impact of initial capital and capital intensity on survival. No negative relationship between firm size and survival is found, and neither the industry growth rate nor the degree of industry innovation is found to be significantly related to the survival of new firms. 
Further, emerging stock markets contain companies that are not necessarily the most profitable ones. In the worst case, firms might even be subject to asset stripping (Johnson et al., 2000), when firm managers, investment funds as owners, and other majority shareholders expropriate resources of the companies at the expense of other (minority) shareholders. Furthermore, the recent global financial crisis has caused listed companies and issuers of bonds a serious disadvantage through credit crunch and unrealized losses on assets (Iwasaki, 2019). However, none of the above conditions promotes firm survival (Baumöhl et al., 2019).

In light of the above-mentioned research, we hypothesize as follows:

H1: Capital structure has an influence on the survival of firms in the stock market.

$\mathrm{H} 2$ : Institutional ownership affects the survival of firms in the stock market.

H3: Major ownership affects the survival of firms in the stock market.

\section{Methodology}

To test the hypotheses, logistic regression is used for parametric survival analysis via Eviews9 software. The sample comprises firms listed on the Tehran Stock Exchange from 2005 to 2015. The sample is selected through the systematic elimination of an initial population. The sample consists of all firms that meet the following criteria. The firm i) is listed on the TSE during the study's sample period; ii) is not a financial firm, including an investment firm, bank, insurance company, or financial institution (as these institutions are unique in terms of the nature of their activities, their main income come from equity investments, and they are dependent on the activities of other firms, they are excluded from the sample); iii) has a financial year ending on March 20th, allowing the data to be put together and presented in panel form, if necessary; iv) has the data covering 2005 to 2015 required for the variables; v) did not change its financial year during the sample period. The sample selection steps are shown in Table 1.

Table 1. Samples selection steps

\begin{tabular}{lccc}
\hline & Total & Number of operating firms & Number of excluded firms \\
\hline Samples (total firms from 1967 to 2015) & 484 & 314 & 170 \\
\hline 1. Excluded firms from before 2005 & -18 & 0 & -18 \\
2. Financial intermediaries and holding firms & -68 & -65 & -3 \\
3. Incorrect financial year & -115 & -73 & -42 \\
4. No access to Exchange information & -49 & 0 & -49 \\
\hline No. of sample & $\mathbf{2 3 4}$ & $\mathbf{1 7 6}$ & $\mathbf{5 8}$ \\
\hline
\end{tabular}

From 2005 to 2015, each firm has 11 sets of extractable financial information from financial statements and related information sources. The data are in panel form, arranged in Excel files based on alphabetical and chronological order and in firm-year form. We used secondary data available in Rahavard-Novin software related to Tehran stock exchange in order to analysis.

Table 2 shows the number of dismissed firms from 2003 to 2015; the year 2009 has the most dismissals (73 firms). Inadequate capital, losses, firm profitability status, amount of free float stock, nonconformity with information disclosure regulations, accumulated losses, and lack of proper disclosure via financial statements are the most common reasons for the dismissal of firms from the Exchange.

Table 2. Number of dismissed firms from the stock market by year (2003-2015)

\begin{tabular}{|c|c|c|c|c|c|c|c|c|c|c|c|c|c|c|}
\hline \multirow{3}{*}{$\begin{array}{l}\text { No. of firms excluded from } \\
\text { the Tehran Stock Exchange }\end{array}$} & \multicolumn{14}{|c|}{ Year } \\
\hline & 2015 & 2014 & 2013 & 2012 & 2011 & 2010 & 2009 & 2008 & 2007 & 2006 & 2005 & 2004 & 2003 & Total \\
\hline & 10 & 13 & 20 & 11 & 0 & 15 & 73 & 10 & 0 & 0 & 15 & 2 & 1 & 170 \\
\hline
\end{tabular}

The following model is used to test the hypotheses:

$\operatorname{In}\left(\frac{\theta_{i}}{1-\theta_{i}}\right)=\alpha 0+\alpha 1$ Capital Structure i, $\mathrm{t}+\alpha 2$ Institutional Ownership $\mathrm{i}, \mathrm{t}+\alpha 3$ Major Ownership i,t $+\alpha 4$ Stock

Price i,t $+\alpha 5$ Profitability i, $t+\alpha 6$ Capital Intensity i, $t+\alpha 7$ Size i, $t+\alpha 8$ Growth i, $t+\alpha 9$ CashFlow i, $t+\varepsilon i, t$ 


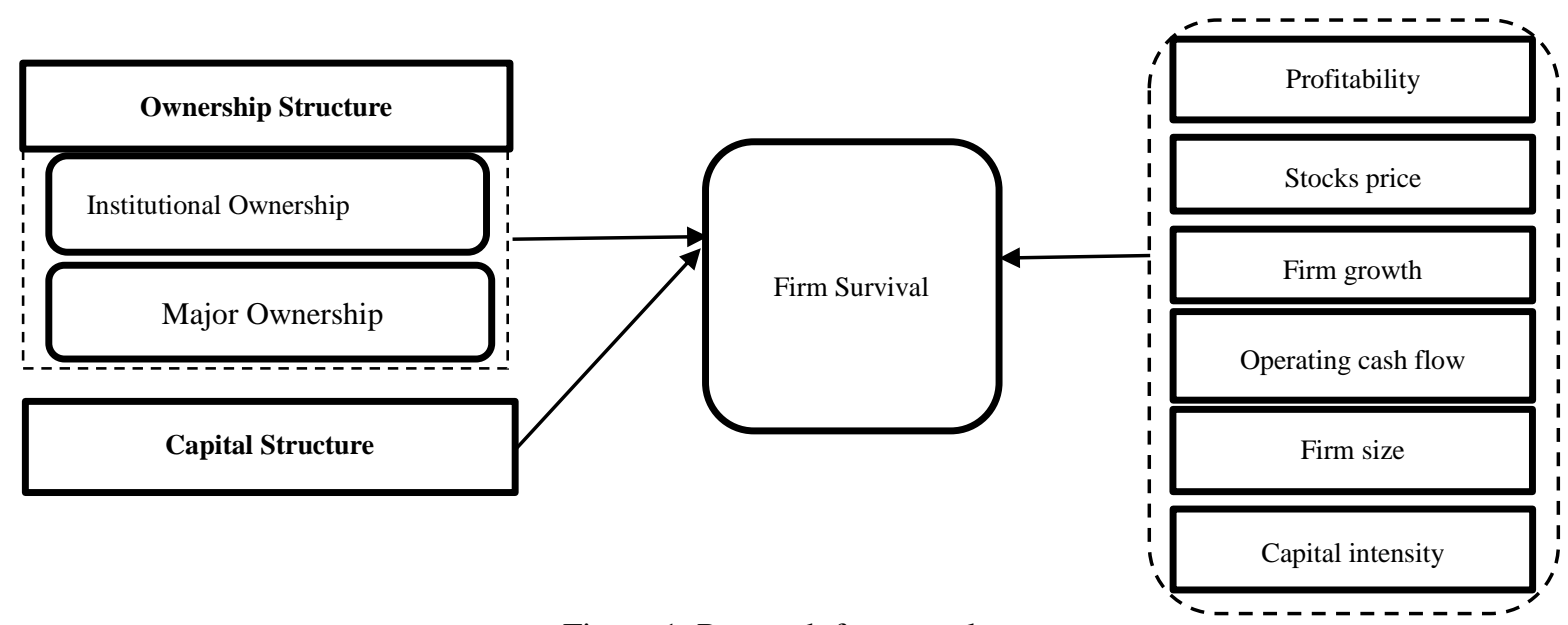

Figure 1. Research framework

The study's dependent variable is EXIT $_{\mathrm{i}, \mathrm{t}}$, reflecting the exit of firm $\mathrm{i}$ in year $\mathrm{t}$ from the list of firms on the Tehran Stock Exchange (one if the firm has left the Exchange and zero otherwise). The independent variables are as follows. Capital Structure $e_{i, t}$ reflects the capital structure of firm $i$ in year $t$ in terms of the ratio of debts to assets (Rahimian et al., 2013). Institutional Ownership $\mathrm{p}_{\mathrm{i}, \mathrm{t}}$ reflects the institutional ownership of firm $\mathrm{i}$ in year $\mathrm{t}$ in terms of the percentage of shares owned by institutions (e.g., investment firms, pension institutions and funds, insurance companies, public and quasi-public entities, charities, Social Security Organization, Mostazafan Foundation, banks and financial institutions, finance companies, investment mutual funds). The control variables are as follows. Major Ownership $\mathrm{i}_{\mathrm{i}, \mathrm{r}}$ reflects the major ownership of firm $\mathrm{i}$ in year $\mathrm{t}$, which is the percentage of shares owned by major shareholders (large shareholders). Stock Price $\mathrm{i}_{\mathrm{i}, \mathrm{t}}$ reflects the stock price of firm $\mathrm{i}$ in year $\mathrm{t}$. Profitability $y_{\mathrm{i}, \mathrm{t}}$ reflects the profitability of firm $\mathrm{i}$ in year $\mathrm{t}$ in terms of the ratio of net profits to assets. Capital Intensity ${ }_{i, t}$ reflects the capital intensity of firm $i$ in year $t$ in terms of the ratio of fixed assets to total assets. Size $e_{i, t}$ reflects the size of firm i in year $t$ in terms of the natural logarithm of total assets. Growth ${ }_{i, t}$ reflects the growth of firm $i$ in year $t$ in terms of the percentage change in total assets in the current year over last year. Finally, CashFlow $_{\mathrm{i}, \mathrm{t}}$ reflects the operating cash flow of firm $\mathrm{i}$ in year $\mathrm{t}$ in terms of the ratio of operating cash flow to total assets.

\section{Analysis and Results}

The mean, median (central standards), standard deviation, maximum and minimum (dispersion standards) values of the variables are calculated and presented in Table 3. The mean is considered the most important central index. It reflects the equilibrium point and the center of gravity of the distribution. As can be seen in Table 3, the mean of the firm exit variable is $27 \%$, indicating a higher dispersion of zero values, and thus a greater lack of exit. The median is the point that divides a sample into two equal parts, whereby $50 \%$ of observations occur before it and $50 \%$ occur after it. As shown in Table 3, the median value of the firm exit variable is zero. The median value shows a greater number of zero values and thus a greater lack of firm exit. The highest and lowest firm exit values are one and zero, respectively. The characteristics of the other variables are presented in Table 3.

Table 3. Descriptive statistics

\begin{tabular}{lccccc}
\hline Variable & Mean & Median & Maximum & Minimum & Standard deviation \\
\hline Firm exit & 0.027 & 0.000 & 1.000 & 0.000 & 0.162 \\
Capital structure & 0.623 & 0.642 & 0.986 & 0.09 & 0.179 \\
Institutional ownership & 66.729 & 78.95 & 99.67 & 0.000 & 30.664 \\
Major ownership & 75.615 & 80.415 & 99.872 & 5.63 & 17.504 \\
Stock price & 5515 & 3188 & 67688 & 143 & 7005 \\
Profitability & 0.1 & 0.091 & 0.639 & -0.681 & 0.149 \\
Capital intensity & 0.257 & 0.215 & 0.888 & 0.001 & 0.178 \\
Firm size & 13.38 & 13.215 & 19.009 & 8.913 & 1.608 \\
Firm growth & 0.164 & 0.121 & 1.648 & -0.481 & 0.252 \\
Operating cash flow & 0.115 & 0.1 & 0.669 & -0.365 & 0.138 \\
\hline
\end{tabular}


We use a Pearson correlation test and logistic regression to explore the relationships between the independent and dependent variables by controlling for the impact of firm-specific variables. To ensure the reliability of the findings, default regression tests are used.

The results of the Pearson correlation test are presented in Table 4. The cells reflect the intersections of the columns and rows, which indicate the values relating to the status of the variable correlations. In each cell, the lower number indicates the significance level of the correlation, which is significant if the level is smaller than 0.05. Table 4 shows a direct correlation between the firm exit and capital structure in the Pearson test as well as a significant inverse correlation between the firm exit and institutional ownership, stock price, profitability, and operating cash flow. Moreover, since the Pearson correlation statistic for the independent and control variables is less than 0.8 in all cases, the model estimation has no autocorrelation problem.

Table 4. Pearson correlation

\begin{tabular}{|c|c|c|c|c|c|c|c|c|c|c|c|}
\hline & Variable & 1 & 2 & 3 & 4 & 5 & 6 & 7 & 8 & 9 & 10 \\
\hline \multirow[t]{2}{*}{1} & Firm exit & 1 & 0.106 & -0.126 & 0.023 & -0.048 & -0.062 & -0.009 & -0.014 & 0.028 & -0.054 \\
\hline & & & 0.000 & 0.000 & 0.332 & 0.048 & 0.011 & 0.684 & 0.547 & 0.247 & 0.027 \\
\hline \multirow[t]{2}{*}{2} & Capital structure & & 1 & -0.054 & 0.082 & -0.14 & -0.584 & -0.124 & 0.008 & -0.032 & -0.309 \\
\hline & & & & 0.024 & 0.000 & 0.000 & 0.000 & 0.000 & 0.724 & 0.182 & 0.000 \\
\hline \multirow[t]{2}{*}{3} & Institutional ownership & & & 1 & 0.513 & 0.17 & 0.182 & 0.094 & 0.261 & 0.007 & 0.147 \\
\hline & & & & & 0.000 & 0.000 & 0.000 & 0.000 & 0.000 & 0.773 & 0.000 \\
\hline \multirow[t]{2}{*}{4} & Major ownership & & & & 1 & 0.107 & 0.019 & 0.017 & 0.004 & -0.002 & 0.056 \\
\hline & & & & & & 0.000 & 0.423 & 0.48 & 0.859 & 0.922 & 0.021 \\
\hline \multirow[t]{2}{*}{5} & Stock price & & & & & 1 & 0.565 & -0.078 & 0.094 & 0.284 & 0.315 \\
\hline & & & & & & & 0.000 & 0.001 & 0.000 & 0.000 & 0.000 \\
\hline \multirow[t]{2}{*}{6} & profitability & & & & & & 1 & 0.009 & 0.119 & 0.279 & 0.513 \\
\hline & & & & & & & & 0.706 & 0.000 & 0.000 & 0.000 \\
\hline \multirow[t]{2}{*}{7} & Capital intensity & & & & & & & 1 & 0.034 & 0.004 & 0.184 \\
\hline & & & & & & & & & 0.161 & 0.858 & 0.000 \\
\hline \multirow[t]{2}{*}{8} & Firm size & & & & & & & & 1 & 0.134 & 0.09 \\
\hline & & & & & & & & & & 0.000 & 0.000 \\
\hline \multirow[t]{2}{*}{9} & Firm growth & & & & & & & & & 1 & -0.047 \\
\hline & & & & & & & & & & & 0.051 \\
\hline 10 & Operating cash flow & & & & & & & & & & 1 \\
\hline
\end{tabular}

*The second row of each variable indicates the significance level.

The Im, Pesaran, and Shin test is used to verify the reliability of the variables. A reliability test confirms if the mean and variance of the variables over time and the covariance of the variables across years are constant, which indicates whether using the variables in a model would lead to a false regression. The result of the test is presented in Table 5. The firm exit variable is excluded from the test due to its specific definition.

Table 5. Im, Pesaran, and Shin test

\begin{tabular}{lcc}
\hline Variables & T statistic & Significance \\
\hline Capital structure & -16.728 & 0.000 \\
Institutional ownership & -10.321 & 0.000 \\
Major ownership & -11.986 & 0.000 \\
Stock price & -9.521 & 0.000 \\
Profitability & -16.801 & 0.000 \\
Capital intensity & -13.732 & 0.000 \\
Firm size & -7.52 & 0.000 \\
Firm growth & -33.613 & 0.000 \\
Operating cash flow & -12.677 & 0.000 \\
\hline
\end{tabular}

The model of the study is estimated below using logistic regression. The results are provided in Tables 6 and 7 . 
Table 6. Findings of hypothesis testing

\begin{tabular}{lcccc}
\hline \multicolumn{1}{c}{ Variable } & Coefficient & SD & Z statistic & Sig. level \\
\hline Constant & -12.542 & 3.894 & -3.220 & 0.001 \\
Capital structure & 9.164 & 2.748 & 3.333 & 0.000 \\
Institutional ownership & -0.03 & 0.008 & -3.628 & 0.000 \\
Major ownership & 0.041 & 0.021 & 1.941 & -0.052 \\
Stock price & -0.0005 & 0.0002 & -2.097 & 0.036 \\
Profitability & 5.892 & 4.107 & 1.434 & 0.151 \\
Capital intensity & 0.707 & 1.408 & 0.502 & 0.615 \\
Firm size & 0.003 & 0.212 & 0.017 & 0.986 \\
Firm growth & 1.479 & 0.923 & 1.602 & 0.109 \\
Operating cash flow & -0.754 & 3.154 & 0.239 & 0.810 \\
McFadden R-square & & & & $\mathbf{0 . 3 3 2}$ \\
LR statistics & & & & $\mathbf{5 3 . 8 3 7}$ \\
LR statistics significance level & & & $\mathbf{0 . 0 0 0}$ \\
\hline
\end{tabular}

$*=$ hypothesis testing at $5 \%$ error level; $* *=$ Hypothesis testing at $10 \%$ error level.

Table 7. Results of hypothesis testing

\begin{tabular}{lr}
\hline Item & Value \\
\hline Akaike info criterion & 0.076 \\
Schwarz criterion & 0.109 \\
Hannan-Quinn criterion. & 0.088 \\
S.D. dependent variable & 0.091 \\
Mean dependent variable & 0.008 \\
S.E. of regression & 0.085 \\
Sum squared residual & 11.958 \\
Log-likelihood & -54.006 \\
Avg. log-likelihood & -0.032 \\
Deviance & 108.012 \\
Restr. Deviance & 161.849 \\
\hline
\end{tabular}

Table 6 shows that the $\mathrm{Z}$ statistic of the capital structure variable is greater than +1.965 and its significance level is less than 0.05; thus, a significant direct relationship exists between capital structure and firm exit, confirming H1. Moreover, the $\mathrm{Z}$ statistic of the institutional ownership variable is greater than -1.965 and its significance level is less than 0.05 ; thus, a significant inverse relationship exists between institutional ownership and firm exit, confirming $\mathrm{H} 2$. On the other hand, the $\mathrm{Z}$ statistic of the major ownership variable is near +1.965 and its significance level is about 0.05 , at a $90 \%$ level of significance (10\% level of error); thus, a significant direct relationship exists between major ownership and firm exit, confirming H3. Regarding the power of the model, the significance level of the LR statistic is below 0.05 , indicating that the model is valid. The LR statistic is 53.837, indicating the high explanatory power of the model. Finally, the McFadden coefficient is 0.332 , indicating that $33 \%$ of the changes in the dependent variable can be explained by the independent and control variables.

\section{Conclusion and Discussion}

The results indicate that an increase in firm debt and major ownership increases the possibility of a firm exit from the stock market and that increased institutional ownership and stock price reduces the possibility of firm exit. The debt ratio thus affects the likelihood of a firm exit. Because debts are accompanied by bankruptcy costs, which may intensify along with the investment deduction problem, an increase in a firm's debt level can destroy firm value (Aggarwal \& Zhao, 2006). This result is in accordance with the Modigliani-Miller theory, hierarchical theory, and static trade-off theory. The study's results regarding the direct relationship between major ownership and firm exit reject the agency theory. The inverse impact of institutional ownership on the possibility of a firm exit from the stock market reflects the fact that institutional investors play an important role in corporate governance. This result is in accordance with the most recent empirical evidence on institutional ownership, firms in financial distress, and confirms the agency theory. Pound (1988) investigates the relationship between investors and earnings management and presents three alternative hypotheses: the efficient monitoring hypothesis, strategic alignment hypothesis, and conflict of interest hypothesis. The efficient monitoring 
hypothesis posits that institutional investors are more specialized than individual shareholders and can monitor managers at a lower cost, thus efficiently limiting managers' earnings management behavior. Contrary to the relationship between institutional ownership and firm survival, the inverse relationship between major ownership and firm survival is inconsistent with recent empirical evidence on major ownership and firms' financial distress. In this study, a high percentage of major owners cause the exit of many firms from the stock market, and a high stock price indicates a higher probability that the company will be listed on Iran's stock market. Moreover, a reduced stock price indicates an increased possibility of a firm exit from the stock market.

The study's statistical tests show that increased firm debt is accompanied by an increased risk of exit. This result contradicts the results in Ebaid (2009), Izadi Nia and Dastjerdi (2009), Khalili Araghi et al. (2009), Zeinali and Mohammad Shilan (2011), and Rahimian et al. (2013) but agrees with those in Aggarwal and Zhao (2006). The finding that institutional ownership has an inverse impact on the probability of firm exit is inconsistent with Tasia and $\mathrm{Gu}$ (2007) and Elsayed and Wahba (2013). More, the finding that major ownership directly and significantly affects the probability of firm exit from the stock market is consistent with Namazi and Kermani (2008) and Esmaeil Zade Maghari et al. (2010). Further, the finding that increased stock prices reduce the probability of firm exit is consistent with Tsoukas (2011). Moreover, the finding that profitability has no significant impact on the probability of firm exit is consistent with Useche (2015). However, the finding that capital intensity does not affect the probability of firm exit contrasts with Rezaei (2013). In addition, the finding that firm size has no significant impact on firm survival contrasts with Mas-Vordu et al. (2015). Furthermore, the finding that firm growth does not influence firm exit or survival in the stock market is consistent with Rezaei (2013). Finally, the finding that operating cash flow has no significant impact on the probability of firm exit contrasts with Tsoukas (2011).

This study's key implications are as follows. The finding of a direct impact of firm debt level on the probability of exit from the stock market implies that investors in listed firms should consider an increase in firm debt as a warning signal. However, an increase or change in the debt level can also have positive impacts, which should also be taken into account when evaluating a firm's debt situation. Overall, managers should pay close attention to increases in debt levels and their negative consequences.

Given the inverse impact of institutional ownership on the probability of firm exit, investors in listed firms should consider an increased percentage of stocks owned by institutions as a positive signal. This could indicate that institutional owners are playing a positive controlling and supporting role in the firms in which they have invested. The direct impact of major ownership on the probability of firm exit shows that investors in listed firms should consider an increased percentage of stocks owned by major shareholders as a negative signal. As the findings of this study also indicate that an increase in stock prices is associated with a lower possibility of firm exit, investors in listed firms should consider an increased percentage of stocks owned by institutions as a positive signal.

The study also shows that incentives should be offered that would foster the establishment of companies in industries such as automotive and parts manufacturing, the pharmaceutical sector, and the cement, lime, and plaster industry while enhancing their chances of survival. Moreover, the Tehran stock exchange should create efficient and experienced scientific and technical centers to provide technical, informational, and managerial advice and assistance for dismissed firms and help them return to the stock market when they prove that they are able to do so.

This study had several limitations. First, the political and economic conditions, as well as the psychological atmosphere surrounding the Tehran Stock Exchange, are factors that may affect the variables considered in this study, but they were not controlled for. Second, the data extracted from financial statements were not adjusted for inflation. However, adjusted data might produce different findings due to the different inflation rates in the studied years. Third, this study used the criteria of major and institutional ownership as indicators of ownership structure. Future studies could use other ownership criteria, such as family ownership or foreign ownership. Finally, the study's dependent variable was firm survival or exit from the stock market. However, future studies may use the probability of firm bankruptcy as the dependent variable and test other aspects of the theories examined in this study.

\section{Acknowledgments}

The second author is deeply grateful to the support provided by JSPS KAKENHI grant number 18K01746.

\section{References}

Abdullah, S. N. (2006). Board structure and ownership in Malaysia: The case of distressed listed companies. 
Corporate Governance: An International Review, 6(5), 582-594.

Acs, Z. J., Braunerhjelm, P., Audretsch, D. B., \& Carlsson, B. (2009). The knowledge spillover theory of entrepreneurship. Small Business Economics, 32(1), 15-30. https://doi.org/10.1007/s11187-008-9157-3

Aggarwal, R., \& Zhao, X. (2007). The leverage-value relationship puzzle: An industry effects resolution. Journal of Economics and Business, 59(4), 286-297. https://doi.org/10.1016/j.jeconbus.2006.07.001

Asadi, Gh. H., Mohammadi, Sh., \& Esmaeil, Kh. (2011).The Relationship between Capital Structure and Ownership Structure. Journal of Accounting Knowledge, 2(4), 29-48.

Audretsch, D. B., Houweling, P., \& Thurik, A. R. (1997). New-Firm Survival: Industry versus Firm Effects. The Economic Journal, 109(454), C140-C155. Retrieved from http://www.tinbergen.nl/discussionpapers/97063.pdf

Baumöhla, E., Iwasakib, I., \& Kočendac, E. (2019). Institutions and determinants of firm survival in European emerging markets, Journal of Corporate Finance, 58, 431-453. https://doi.org/10.1016/j.jcorpfin.2019.05.008

Che, Y., Lu, Y., \& Tao, Z. (2017). Institutional quality and new firm survival. Econ. Transit., 25(3), 495-525. https://doi.org/10.1111/ecot.12119

Dellana, S., Dellana, S., West, D., \& West, D. (2016). Survival analysis of supply chain financial risk. The Journal of Risk Finance, 17(2), 130-151. https://doi.org/10.1108/JRF-11-2015-0112

Dollinger, M. J. (1999). Entrepreneurship strategies and resources, Richard D. Irwin, Homewood. The Economic Journal, 109(454), C140-C155.

Dzhumashev, R., Mishra, V., \& Smyth, R. (2011). Exporting, R\&D investment and firm survival. Monash University. Department of Economics. Discussion paper, pp. 11-39.

Ebaid, I. E. (2009). The impact of capital-structure choice on firm performance: Empirical evidence from Egypt. The Journal of Risk Finance, 10(5), 477-487. https://doi.org/10.1108/15265940911001385

Elloumi, F., \& Gueyle, P. J. (2001). Financial distress and corporate governance: An empirical analysis. Corporate Governance, 1(1), 15-23.

Elsayed, K., \& Wahba, H. (2013). Reinvestigating the relationship between ownership structure and inventory management: A corporate governance perspective. International Journal of Production Economics, 143(1), 207-218.

Ely, D. P., \& Song, M. H. (2000). Acquisition activity of large depository institutions in the 1990s: An empirical analysis of motives. Quarterly Review of Economics and Finance, 40(4), 467-484

Esmaeil, Z. M. A., Jalili, M., \& Zand, A. A. (2010). Investigting the Impact of Corporate Governance on Earnings Quality in Tehran Stock Exchange. Journal of Management Accounting, 7, 79-91.

Faruq, H. A., \& Weidner, M. L. (2018). Culture, institutions, and firm performance. East. Econ. J., 44(4), 519-534. https://doi.org/10.1057/s41302-016-0087-5

Fidrmuc, J., Kapounek, S., \& Siddiqui, M. (2017). Which institutions are important for firms' performance? Evidence from Bayesian model averaging analysis. Panoeconomicus, 64(4), 383-400. http://dx.doi.org/10.2298/PAN151015031F

Fritsch, M., Brixy, U., \& Falck, O. (2006). The effect of industry, region, and time on new business survival-a multi-dimensional analysis. Review of Industrial Organization, 28(3), 285-306. https://doi.org/10.1007/s11151-006-0018-4

Ghahroudi, R. M. (2011). Ownership advantages and firm factors influencing performance of foreign affiliates in Japan. International Journal of Business and Management, 6(11), 119-137. https://doi.org/10.5539/ijbm.v6n11p119

Ghahroudi, R. M. (2016). The relationship between entry mode, capital and technology in Iran's FDI. Journal of Planning and Budgeting, 21(3), 143-184.

Ghahroudi, R. M., \& Hoshino, Y. (2007). Establishment, survival, sales growth ratio and entry strategies of Japanese MNCs subsidiaries in India. Journal of Developmental Entrepreneurship, 12(4), 433-447. https://doi.org/10.1142/S1084946707000745

Ghahroudi, R. M., Hoshino, Y., \& Turnbull, J. S. (2010). Assets growth, foreign ownership and type of industry 
in Multinational Companies, International Business Research, 3(4), 244-255.

Ghoul, S., Guedhami, O., \& Kim, Y. (2017). Country-level institutions, firm value, and the role of corporate social responsibility initiatives. J. Int. Bus. Stud., 48(3), 360-385. https://doi.org/10.1057/jibs.2016.4.

Görg, H., \& Spaliara, M. E. (2014). Financial health, exports and firm survival: Evidence from UK and French firms. Economica, 81(323), 419-444. https://doi.org/10.1111/ecca.12080

Guariglia, A., Spaliara, M. E., \& Tsoukas, S. (2016). To what extent does the interest burden affect firm survival? Evidence from a panel of UK firms during the recent financial crisis. Oxford Bulletin of Economics and Statistics, 78(4), 576-594. https://doi.org/10.1111/obes.12120

Hiugbert, S. A., Hogg, G., \& Quinn, T. (2006). Consumer response to social entrepreneurship: The case of the Big Issue in Scotland. International Journal of Nonprofit and Voluntary Sector Marketing, 7(3), 288-301. https://doi.org/10.1002/nvsm.186

Iwasaki, I. (2014). Global financial crisis, corporate governance, and firm survival: The Russian experience. Journal of Comparative Economics, 42, 178-211.

Iwasaki, I., \& Kočenda, E. (2019). Survival of service firms in European emerging economies. Applied Economics Letters, Forthcoming.

Izadi, N. N. ,\& Rahimi, D. M.. (2009). The Impact of Capital Structure on the rate of Stock Returns and Earnings per Share. Journal of Accounting Research, 3, 136-161.

Jensen, M. C., \& Meckling, W. H. (1976). Theory of the firm: Managerial behavior, agency costs and ownership structure. Journal of Financial Economics, (October), 305-360.

Johnson, S., La Porta, R., Lopez-de-Silanes, F., \& Shleifer, A. (2000). Tunneling. Am. Econ. Rev., 90(2), 22-27.

Khalili, A. M., Akbari, M. B., \& Ata, E. M. (2009). The Impact of Environmental Risk, Firm Strategy, and Capital Structure on Firms Performance in Petrochemical Industry. Journal of Management Development and Transformation, 1, 7-41.

Kirchhoff, B. A. (1994). Entrepreneurship and dynamic capitalism. The economics of business firm formation and growth, $\mathrm{ABC}-\mathrm{CLIO}$ publication.

Klapper, L., \& Richmond, C. (2011). Patterns of business creation, survival and growth: Evidence from Africa. Labour Economics, 18, S32-S44. https://doi.org/10.1016/j.labeco.2011.09.004

Kraus, A., \& Litzenberger, R. H. (1973). A state-preference model of optimal financial leverage. The Journal of Finance, 28(4), 911-922.

Liang, L. W., Cheng, C. P., \& Lin, Y. P. (2015). A study of the relationship between bank survival and cost efficiency. Journal of Finance, 3(2), 35-47. https://doi.org/10.15640/jfbm.v3n2a4

Lomi \& Larsen. (1998). Density Delay and Organizational Survival: Computational Models and Empirical Comparisons. Computational \& Mathematical Organization Theory, 3(4), 219-247.

Mahmood, T. (2000). Survival of newly founded businesses: A log-logistic model approach. Small Business Economics, 14(3), 223-237. https://doi.org/10.1023/A:1008116207175

Mas-Verdu, F., Ribeiro-Soriano, D. \& Roig-Tieno, N. (2015). Firm survival: The role of incubators and business characteristics. Journal of Business Research, 68(4), 793-796. https://doi.org/10.1016/j.jbusres.2014.11.030

Megginson, W. L. (2016). Privatization, state capitalism, and state ownership of business in the 21 st century. Found. Trends Finance, 10(3-4), 181-362. http://dx.doi.org/10.1561/0500000053

Modigliani, F., \& Miller, M. H. (1958). The cost of capital, corporation finance and the theory of investment. American Economic Review, 48, 97-261.

Modigliani, F., \& Miller, M. H. (1963). Corporate income taxes and the cost of capital: A correction. American Economic Review, 53, 433-443.

Morikawa, M. (2013). Productivity and survival of family firms in Japan. Journal of Economics and Business, 70, 111-125. https://doi.org/10.1016/j.jeconbus.2012.11.001

Myers, S. C., \& Majluf, N. S. (1984). Corporate Financing and Investment Decisions when Firms Have Information that Investors Do Not Have. Journal of Financial Economics, 13(2), 187-221.

Najjar, B., \& Taylor, P. (2008). The Relationship between Capital Structure and Ownership Structure. Managerial Finance, 12, 919-933. https://doi.org/10.1108/03074350810915851 
Namazi, M., \& kermani, E. (2008). The impact of ownership structure on the performance of firms listed in Tehran stock exchange. Accounting and Auditing Investigations, 53, 83-100.

Pommet, S. (2013). The impact of venture capital investment duration on the survival of French IPOs. Retrieved from http://gretha.u-bordeaux.fr/fr

Pound, J. (1988). Proxy contests and the efficiency of shareholder oversight. Journal of Financial Economics, 20, 237-265.

Rahimian, N., Tavakolnia, E., \& Tirgari, M. (2013). Investigate the Curved Relationship of Capital Structure with the Performance and Value of Firms Listed in Tehran Stock Exchange. Scientific Quarterly Journal of Financial Knowledge of Securities Analysis, 6(19), 67-79.

Rezaei, F. (2013). Investigating the impact of industry and firm attributes on the survival of new firms in electronic \& electric industries in Mazandaran province. MA Thesis in Industrial Management, University of Mazandaran.

Ross, S. (1977). The determination of financial structure: The intensive signaling approach. Bell Journal of Economics, 8, 23-40.

Shane, S. (2000). Prior knowledge and the discovery of entrepreneurial activities. Organization Science, 11, 448-469.

Sui, S., \& Baum, M. (2014). Internationalization strategy, firm resources and the survival of SMEs in the export market. Journal of International Business Studies, 45(7), 821-841. https://doi.org/10.1057/jibs.2014.11

Taylor, M. P. (1999). Survival of the fittest? An analysis of self-employment duration in Britain. The Economic Journal, 109(454), 140-155.

Tsai, H., \& Gu, Z. (2007). The relationship between institutional ownership and casino firm performance. International Journal of Hospitality Management, 26(3), 517-530.

Tsoukas, S. (2011). Firm survival and financial development: Evidence from a panel of emerging Asian economies. Journal of Banking \& Finance, 35, 1736-1752. https://doi.org/10.1016/j.jbankfin.2010.12.008

Useche, D. (2015). Patenting behavior and the survival of newly listed European software firms. Industry and Innovation, 22(1), 37-58. https://doi.org/10.1080/13662716.2015.1013733

Velu, C. (2015). Business model innovation and third-party alliance on the survival of new firms. Technovation, 35, 1-11. https://doi.org/10.1016/j.technovation.2014.09.007

Wahlqvist, I. (2014). The Capital Structure, Ownership and Survival of Newly Established Family Firms (Doctoral dissertation, BI Norwegian Business School).

Wilson, N., Wright, M., \& Altanlar, A. (2014). The survival of newly incorporated companies and founding director characteristics. International Small Business Journal, 32(7), 733-758. https://doi.org/10.1177/0266242613476317

Wilson, N., Wright, M., \& Scholes, L. (2013). Family business survival and the role of boards. Entrepreneurship Theory and Practice, 37(6), 1369-1389. https://doi.org/10.1111/etap.12071

Yasar, M., Paul, C. J. M., \& Ward, M. R. (2011). Property rights institutions and firm performance: A cross-country analysis. World Dev., 39(4), 648-661. https://doi.org/10.1016/j.worlddev.2010.09.009

Zeinali, M., \& Mohammad, S. J. (2011). Investigating the Impact of Capital Structure on Size, Rate of Stock Returns, and Earnings per Share of Firms Listed in Tehran Stock Exchange (case study: Pharmaceutical Industry). Journal of Financial Knowledge of Securities Analysis, 9, 43-60.

\section{Copyrights}

Copyright for this article is retained by the author(s), with first publication rights granted to the journal.

This is an open-access article distributed under the terms and conditions of the Creative Commons Attribution license (http://creativecommons.org/licenses/by/4.0/). 